\title{
Developing countries versus multinationals in a globalising world: the dangers of falling behind
}

Citation for published version (APA):

Dunning, J. H., \& Narula, R. (1996). Developing countries versus multinationals in a globalising world: the dangers of falling behind. MERIT, Maastricht Economic Research Institute on Innovation and Technology. MERIT Research Memoranda No. 013 https://doi.org/10.26481/umamer.1996013

Document status and date:

Published: 01/01/1996

DOI:

10.26481/umamer.1996013

Document Version:

Publisher's PDF, also known as Version of record

\section{Please check the document version of this publication:}

- A submitted manuscript is the version of the article upon submission and before peer-review. There can be important differences between the submitted version and the official published version of record.

People interested in the research are advised to contact the author for the final version of the publication, or visit the DOI to the publisher's website.

- The final author version and the galley proof are versions of the publication after peer review.

- The final published version features the final layout of the paper including the volume, issue and page numbers.

Link to publication

\footnotetext{
General rights rights.

- You may freely distribute the URL identifying the publication in the public portal. please follow below link for the End User Agreement:

www.umlib.nl/taverne-license

Take down policy

If you believe that this document breaches copyright please contact us at:

repository@maastrichtuniversity.nl

providing details and we will investigate your claim.
}

Copyright and moral rights for the publications made accessible in the public portal are retained by the authors and/or other copyright owners and it is a condition of accessing publications that users recognise and abide by the legal requirements associated with these

- Users may download and print one copy of any publication from the public portal for the purpose of private study or research.

- You may not further distribute the material or use it for any profit-making activity or commercial gain

If the publication is distributed under the terms of Article $25 \mathrm{fa}$ of the Dutch Copyright Act, indicated by the "Taverne" license above, 


\title{
DEVELOPING COUNTRIES VERSUS MULTINATIONALS IN A GLOBALISING WORLD: THE DANGERS OF FALLING BEHIND
}

John H. Dunning and Rajneesh Narula

\begin{abstract}
Forthcoming in, Peter Buckley and Pervez Ghauri (eds), Multinational Enterprises and Emerging Markets: Managing Increasing Interdependence, London: Dryden Press, 1997
\end{abstract}

$\underline{\text { INTRODUCTION }}$

The nature and extent of the interaction between MNEs and governments of developing countries has undergone several dramatic shifts over the post war era. Partly, this is a result of fundamental changes in political ideologies and in the economic systems associated with these ideologies. This has led to a wide variety of policies, attitudes and actions by governments towards MNE activity, which has spanned the continuum between the laissez-faire, neo-liberal approach maintained by the pre-1997 Hong Kong government and the structural adjustment programmes sponsored by the World Bank on the one hand;, and the centrally-planned administrative systems of Eastern European countries and the People's Republic of China on the other. This heterogeneity of policies is, in itself, unsurprising, given the different stages of development and economic structure of these countries. However, over-arching these variables, and influencing them, has been the radical reorientaion of development strategies by many developing countries over the past two decades from those of an import-substituting and inward looking variety towards those geared towards outward looking and export-oriented goals. These have led to an even wider variety of policy orientations as countries have undertaken structural adjustment programmes, while preserving certain elements of their former regimes.

The present thrust towards MNE-friendly attitudes by governments dates back to the early 1980s, and can be prescribed to broad changes in the world economy which have been generically (although not always appropriately) been described as "globalisation". We use this term to signify the growing convergence of income levels and consumption patterns between industrialised and several industrialising countries, and the increasing interdependence between these countries. The primary determinants of globalisation have been (i) the rapid development of information and computer technologies (ICT) and the continued fall in real transport and transaction costs ; and (ii) the renaissance of democratic capitalism and the free market system of allocating scarce resources. However, globalisation has by not affected all countries and regions to the same extent, especially in the developing world. While a small handful of developing countries have prospered, a vast majority have experienced a corresponding divergence of their income levels and consumption patterns away from their counterparts in the industrialised world.

This has resulted in what is essentially a dichotomy of countries, viz, a widening in the income levels of the wealthiest industrialised countries (and a handful of wealthier developing countries) at one extreme and the poorest countries at the other. Indeed, as argued by Gray (1996), globalisation, while benefiting the 
middle income developing countries, has so far brought relatively few economic gains to the least developed countries, e.g., most of sub-Saharan Africa.

These related processes have fundamentally altered the relationship between MNEs and governments, as both institutions have adjusted their strategies and policies to the realities of the new global environment. Although a growing number of developing countries have adopted development strategies that increasingly rely on inbound foreign direct investment (FDI) to upgrade their indigenous resources and improve the competitiveness of their domestic industries, most have been unable to replicate the success stories of the Asian newly industrialising countries (NICs). Essentially these countries are stuck in a vicious circle, which, in great measure, is due to their failure to improve their human and technological infrastructure, macro-economic policies and institutional frameworks. This vicious circle is also exacerberated by the increased competition for FDI inflows among the developing countries, which has led to a dissipation of potential net benefits from MNE activities through a series of locational tournaments (Mytelka 1996).

This chapter is organised as follows. Section 1 traces the changing geographical configuration of MNE activity and of economic growth over the past two decades. In particular, it suggests that while there has been some convergence in the living standards of some of the upper and middle income countries, there has been an increasing polarization between these and those of the poorer countries. Section 2 and 3 go on to suggest reasons for the widening of income gaps, and evaluate the respective roles which MNEs and governments may play in reducing them. Section 4 presents some policy implications for developing economies, emphasising the need for MNEs and governments to view each other's roles as complementary, since the upgrading of resources and capabilities of countries improves the net benefits to both parties.

\section{THE RESURGENCE OF INTEREST IN MNE-GOVERNMENT RELATIONS}

The relationship between MNEs and democratic national governments is governed by a fundamental difference in the objectives of each. The MNE, as with most private economic entities desires to maximise the welfare of its owners ${ }^{1}$, while the national government wishes to do the same for its citizens. Although not a zero-sum game - even where the relationship is not confrontational - the failure to find common ground often results in a sub-optimal outcome for both parties. Indeed, in the 1970s, most governments viewed MNEs with a certain amount of hostility. Since that time much has changed, with both MNEs and governments coming to realise that each has much to offer the other; and that a cooperative rather than an adversarial association may best promote mutual interests. In the 1990s both players are taking an more systemic and integrated approach towards upgrading their resource creation and usage, and maintaining their long-term competitiveness. This has led to a more pragmatic approach by national governments to MNE activity. Such a shift in approach and attitude, especially among developing countries, which hitherto have had a confrontational approach to inbound FDI must be seen in the light of dramatic events that have taken place in

1 This is used in the sense suggested by Nelson and Winter (1982), that is that firms can in reality only satisfice - since they are boundedly rational, they maximise within the constraints imposed by their lack of perfect information. 
the world economy. Before examining the changes that have occurred in the government-MNE interface, it is germane to understand the underlying reasons behind these changes, not just in the interaction between these two sets of actors, but within each set of players. While there has been a tendency to classify much of the changes of the past 20-25 years under the heading of "globalisation", this entails a simplification of several complex phenomena which, together, have fashioned a reconfiguration of the world economy and the way in which it is organised. In particular the last decade of the 20th century has seen a reorientation in the socioinstitutional structure of democratic capitalism from hierarchical to alliance capitalism (Dunning 1994, 1995).

Despite this new era of economic pragmatism and the increased cooperation between MNEs and national governments, globalisation has not occurred evenly across industries and countries. Indeed, globalisation can be said to have led to a increased segregation of countries into three broad categories. The first consists of the wealthy industrialised countries which, over the few decades, have experienced a convergence in income levels, consumption patterns and technological capabilities. The second comprises the (primarily Asian) NICs, which are also catching up and converging with the first group. The third category is made up of a large number of developing countries, which far from converging with the first and second group are in fact diverging away them, either because they have 'stayed behind' relative to the first group, or because they have 'stumbled back' in both a relative and absolute sense (Hikino and Amsden 1994). Put another way, the homogeneity among markets that is associated with globalisation has occurred on a regional, rather than a global basis. These processes have been the subject of considerable research, which tried to explain the slowdown of productivity growth amongst the industrialised countries, as well as the long run tendency for income levels and productivity levels to converge in the long-run with that of the lead country. The main thesis of the convergence theory is that the lead country possesses the largest capital stock and the highest level of technology and knowledge. The greater the gap between the lag and the lead country, the larger is the pool of potential created assets ${ }^{2}$ the follower country may acquire - and provided it possess the capabilities to harness these assets - the greater the potential for economic growth.

The divergence of the majority of the lower income developing countries has been illustrated by Dowrick and Gemmell (1991) and Alam and Naseer (1992), among others. This divergence has occurred despite technological catch-up due to the proliferation of the activities of MNE's, the integration of world markets and information technology, each of which should, in theory at least, increase spillovers of wealthcreating assets to lagging countries. This convergence of income, technological and knowledge levels of the niddle and higher income countries has furthered the homogeneity of their consumption patterns and markets, leading to a sort of de facto integration amongst the countries of the Triad, in addition to the de jure integration within sub-groups such as the European Union and NAFTA (Narula 1993, 1995, Dunning and Narula 1994).

2 The distinction between natural and created assets is an important one. Natural assets may be defined as fruits of the earth and include the stock of untrained labour and resource endowments. Created assets are those that derive from the upgrading of these natural assets. They may be tangible (for example, the stock of physical and financial assets) or intangible (for example technological knowhow, goodwill, managerial and entrepreneurial skills, interpersonal relationships, forged by individuals, and culture and organisational structure of institutions).) 
The simultaneous divergence of the growth and income levels between richer and poorer economies, and the convergence amongst industrial (and rich) economies, harkens back to the vicious cycle of poverty. The inability of the least developed countries to escape from the vicious cycle, and therefore to converge, can be explained by the absence of the same conditions that underly convergence within the developed countries, viz., that while technological spillovers assist productivity growth in industrialised economies, nonindustrialised, poorer economies are unable to utilise such spillovers either because they are not available to them or because the countries do not have the appropriate social-institutional systems and the necessary technological and organisational capability ${ }^{3}$.

\section{GLOBALISATION AND MNE ACTIVITY}

MNE activity, by its very definition, implies cross-border activity, and it is self-evident that this trend towards homogeneity of incomes and consumption patterns has been considerably assisted by the activities of MNEs. Indeed, the growth of MNE activity in all its forms has been unprecedented over the past fifteen years, growing faster than trading activities or overall economic growth (Table 1). Other research by the current authors (Dunning 1996, Narula 1995, Dunning and Narula 1994, 1995) suggests that with the exception of China ${ }^{4}$ MNE activity has become more concentrated among the higher and middle income countries.

TABLE 1: Selected indicators of FDI and international production, 1986-95 (billions of US dollars and percentages)

\begin{tabular}{|lccc|}
\hline & \multicolumn{3}{c|}{$\begin{array}{c}\text { Annual growth } \\
\text { rate (per cent) }\end{array}$} \\
Indicator & $\begin{array}{c}\text { Value at current } \\
\text { prices, 1995 }\end{array}$ & $1986-1990$ & $1991-1994$ \\
\hline FDI inflows & 315 & 24.7 & 12.7 \\
FDI outward stock & $2730^{\mathrm{b}}$ & 19.8 & 8.8 \\
$\begin{array}{l}\text { Sales of foreign affiliates of } \\
\text { MNEs }\end{array}$ & 6022 & 17.4 & 5.4 \\
Royalties and fees receipts & $41^{\mathrm{d}}$ & 21.8 & 10.1 \\
GDP at factor costs & $24948^{\mathrm{d}}$ & 10.8 & 4.3 \\
Gross product of foreign & $1410^{\mathrm{e}}$ & 10.8 & $11.4 \mathrm{~g}$ \\
affiliates & $5681^{\mathrm{d}}$ & $11.0^{\mathrm{f}}$ & 4.0 \\
Gross fixed capital formation & &
\end{tabular}

\footnotetext{
${ }^{3}$ However, the divergence trend of productivity growth is true only for the industrial sector, while in agriculture there has been catch-up by poorer economies (Dowrick 1992). Therefore, a second explanation for the divergence can be the failure of non-industrialised economies to restructure their economic structure away from an agricultural base to an industrial one.

${ }^{4}$ which between 1990 and 1994 accounted for $8.4 \%$ of all inward FDI.
} 


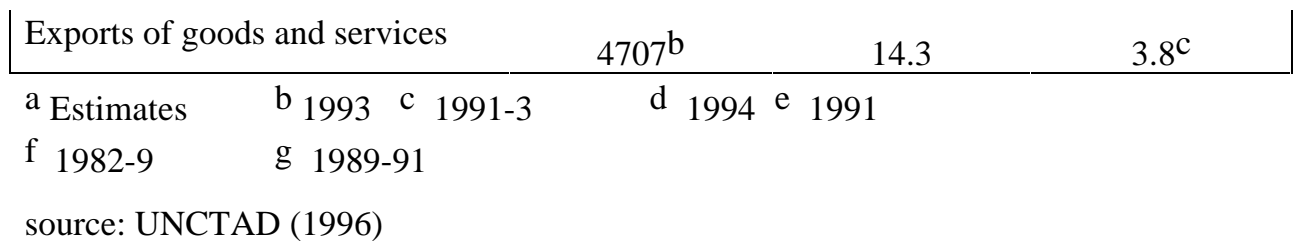

Among other features of FDI trends in recent years, one might highlight the following:

1. Both inbound and outbound FDI as a percentage of GDP has substantially increased for almost all countries;

2. The primary source of outbound FDI continues to be the industrialised countries. These countries accounted for $95.0 \%$ of such investment in the period 1980 and $89.4 \%$ in the period 1990-94, having increased their share of outward FDI stock between 1980 and 1993 from $79.1 \%$ to $79.4 \%$;

3. Though there has been a marked increase in the total outward FDI from developing countries ${ }^{5}$. Developing countries accounted for jut $0.3 \%$ of annual average FDI outflows worldwide during the period 1970-79, and

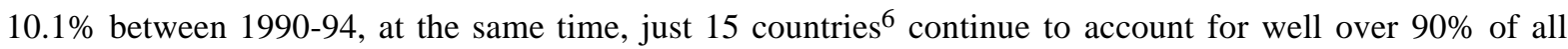
developing country outward FDI stocks (Dunning, Hoesel and Narula 1996);

4. Around $70 \%$ of FDI from the Triad countries is being directed towards other Triad countries. Although, as Table 2 shows, there has been an increase in the share of inward FDI to developing countries, this increase almost entirely represents an increase to a small group of developing countries which primarily includes the Asian NICs and China. Thus between 1980 and 1993, China and the Asian NICs increased their share of total worldwide inward FDI stocks from $2.4 \%$ and $0.7 \%$ to $3.9 \%$ and $2.7 \%$ respectively;

5. Of the 'new' outward investors from developing countries, an increasing share of the investment is being made in industrialised countries rather than in other developing countries (Dunning, Hoesel and Narula 1996); 6. Once the oil-exporting countries are excluded, Asia would appear to be the only continent (Table 2) which has experienced an increase in its share of inward FDI. Although Asia would appear to have experienced a marginal increase in its share of GDP, this is primarily due to the NICs;

7. Despite a decline in the in GDP, the ratio of inward FDI stock to GDP - which is a proxy for the role of MNE activity in the host economy - has increased significantly for non-oil exporting developing countries, from $5.24 \%$ in 1980 to $12.25 \%$ in 1993. More interestingly, a similar trend is observable in Africa and Latin America;

8. An increasing amount of FDI (over 50\%) is being allocated to tertiary sector;

9. The growth of strategic alliances and other quasi-market forms of activity remains primarily an industrialised country MNE phenomenon (Freeman and Hagedoorn 1995).

In the context of the present chapter, the increasing share of FDI stocks relative to GDP across all developing countries is particularly relevant. Even among the low income countries, only seven of the twenty

${ }^{5}$ From an annual average of $\$ 49.5$ billion in 1980-84 to $\$ 215.5$ billion in 1990-94.

${ }^{6}$ These countries are China, India, Brazil, Colombia, Philippines, Thailand, Mexico, Chile, Venezuela, Hong Kong, Korea, Malaysia, Singapore and Taiwan. 
four non-oil exporting, low income countries experienced a decline in their FDI to GDP ratio. In the case of the lower middle income countries, only three experienced a decline in this ratio ${ }^{7}$. This increase in significance can partly be explained by the decline in the GDP levels due to the economic and technological divergence of a majority of these countries. Nonetheless, there has also been an increase in FDI flows to a number of developing countries not all of whom have experienced catching-up. For instance, Argentina received 5.5\% of all inflows to developing countries over the period 1990-94, twice that of Hong Kong in the same period. This increased inflow to developing countries may partly be in response to privatisation programmes amongst countries undertaking structural adjustment programmes - $7.6 \%$ of inflows to developing countries between 1989 and 1993 represented FDI from privatisation (UNCTAD 1996).

\section{TABLE 2: Significance of Regions in World GDP and inward FDI Stocks, 1980 and 1993}

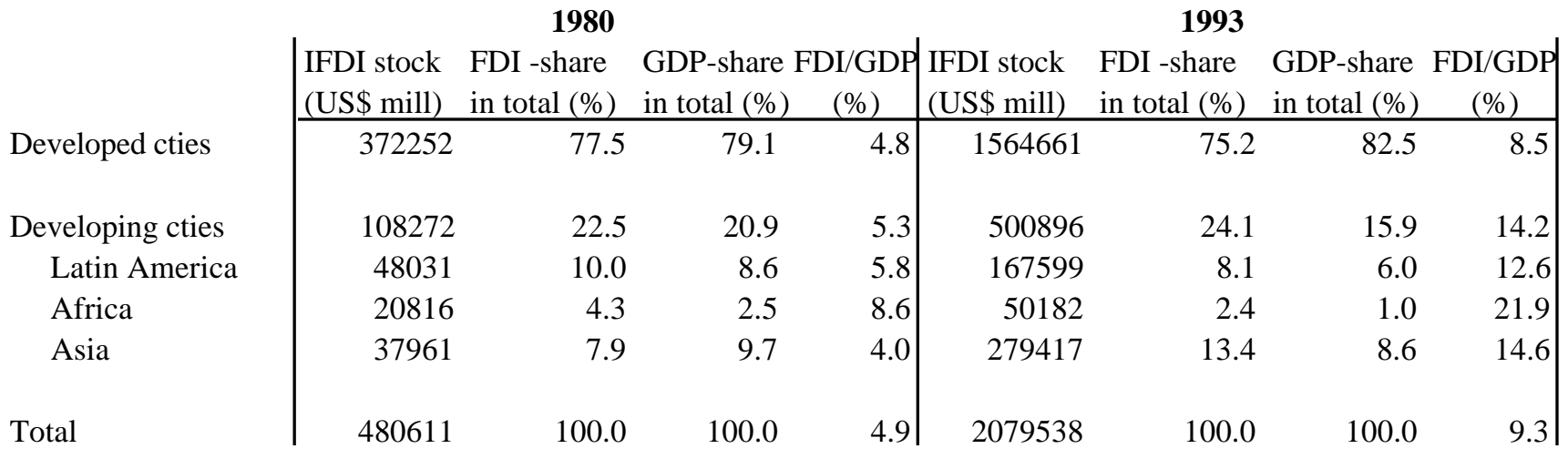

\section{Addenda: developing countries less oil exporters}

\begin{tabular}{l|rrrr|rrrr|} 
Developing less & & & & & & & & \\
oil exporting cties & 66377 & 13.8 & 13.0 & 5.2 & 315707 & 15.2 & 11.6 & 12.3 \\
$\quad$ Latin America & 35319 & 7.3 & 5.1 & 7.1 & 113579 & 5.5 & 4.1 & 12.5 \\
Africa & 13077 & 2.7 & 0.9 & 14.5 & 17359 & 0.8 & 0.4 & 19.2 \\
Asia & 16517 & 3.4 & 6.8 & 2.5 & 181070 & 8.7 & 6.8 & 11.9 \\
$\quad$ Asian NICs & 11477 & 2.4 & 1.5 & 7.8 & 81880 & 3.9 & 3.0 & 12.4 \\
$\quad$ China & 3444 & 0.7 & 2.7 & 1.3 & 57172 & 2.7 & 1.9 & 13.4 \\
Asia less & & & & & & & & \\
China and NICs & 1596 & 0.3 & 2.6 & 0.6 & 42018 & 2.0 & 2.0 & 9.7
\end{tabular}

SOURCE: UNCTAD 1995, World Bank (1995)

Note: GDP data is based on sample of 91 countries for which both FDI and GDP data are available for both periods Note: the GDP share of China is considerably underestimated due to exchange rate fluctuations

Thus, the evidence would suggest that the role of MNEs in the diverging economies not only continues to be significant, but has actually increased over the past decade. Indeed, as Table 2 shows, this role is much larger in the developing countries than in the industrialised countries. For low income countries, the ratio of FDI to GDP has increased from an average of $8.7 \%$ in 1980 to $10.2 \%$ in 1993, while for low middle

\footnotetext{
${ }^{7}$ Income level classifications are based on those used by the World Development Report.
} 
income countries this ratio has increased from $10.0 \%$ to $12.2 \%$ in the same years. Indeed, we would venture to suggest that had MNEs not maintained their investments (and in some cases increased it), the divergence of these countries might have been considerably greater.

With ten developing host countries accounting for 67\% of inward FDI stock and 79\% inward FDI flows in 1993, this would suggest that, with the increasing reliance of less developed countries on FDI as a source of capital, technology and knowledge, there is increasing likelihood that there will be further polarisation of the world economy and widening of the gap between the Triad and the bulk of developing countries. However, despite the fact that the role of MNEs in these countries has increased, opportunities for sequential investments are considerably limited, especially in higher value added activities and sectors which provide significant potential spillovers. In an analysis of the effects of global integration on development, Gray (1996) predicts that the marginal net benefits from international involvement will decline with globalisation for the least developed countries. He suggests that the benefits of globalisation are selfreinforcing: the inability of these countries to attract inward FDI that results in positive spillover effects are likely to offer few opportunities for exports and inflows of portfolio capital. Underlying the relative decline of interest by MNEs in the diverging countries are three inter-related phenomena. First, there has been a significant reconfiguration in the way both MNEs conduct and coordinate their international operations. Second, there has been a fundamental change in the nature and type of immobile location-specific created assets to which MNEs are interested in acquiring access. Third, there has been a significant shift in the expectations of countries from MNE activity. These underlying determinants have each affected the strategies and activities of MNEs differently, and the consequences and nature of these changes will be examined throughout the remainder of this chapter. Not coincidentally, these changes are directly associated with the economic changes associated with the advent of globalisation, and can be broadly traced to two fundamental changes in the world economy: (i) developments associated with the introduction and adoption of new technologies, which have drastically reduced real transport and transaction costs; and (ii) the renaissance of capitalism and the end of the cold war.

\section{(i) New technologies}

The growth of new technologies have had a significant impact on the means by which MNEs view countryspecific advantages. Central among these have been a series of spectacular advances in information and computer technologies (ICT's), which some scholars believe are initiating a new technological paradigm around which a new Kondratieff cycle of economic change will cluster (Freeman 1987, Freeman and Perez 1988). ICT's have dramatically shrunk the economic distance between countries, and have facilitated a series of generic productivity improvements. Needless to say, their rapid development over the past two decades has further enhanced the process of globalisation, of both countries and firms. They have done so through at least three means.

First, new technologies have led to improved coordination of cross-border activities. It is a fundamental feature of MNE activity that cross-border market failure exists in the supply of intermediate products, and especially intangible assets. ICT has reduced both the costs of acquiring and disseminating information, and the transaction and coordination costs associated with cross-border activity. This is on at 
least two levels. First, information about both input and output markets is more easily accessible. This allows firms which previously could not engage in international business transactions now to do so. Indeed, a UN study (1993) has indicated that there is an increasing number of small and medium enterprises engaging in international activity than was hitherto the case. Second, MNEs are better able to integrate the activities of their various affiliates through the use of these technologies and to more quickly respond to changing conditions in the countries in which they operate. Taken together, these transaction cost-reducing processes have enabled MNE activity to be much more efficiently organised across borders. They have also facilitated a shift towards more rationalised and strategic asset-seeking MNE activity, and away from the more multidomestic approach which was more prevalent prior to the 1970s.

While the decline of transactions and coordinating costs has led to an increased efficiency of intrafirm networks, there have also been substantial cost-savings in the coordination and monitoring costs associated with inter-firm networks. This growing use of networks, both intra- and inter-firm, is one of the primary features of the age of alliance capitalism (Dunning 1995, Gerlach, 1992). The use of strategic alliances, joint ventures, R\&D consortia and the like has experienced rapid growth, both within and between countries (Hagedoorn and Narula, 1996). Indeed, the growing use of organisational modalities which permit firms to engage in quasi-internalised arrangements is attributable, at least in part to the ease with which collaborators and competitors may be monitored, and the extent to which the risks of shirking have declined (Duysters and Narula 1996). In case of the converging and catching-up economies, larger markets for similar products and the ability of MNEs to organise production activities on a rationalised basis has led, ceteris paribus, to higher rents, allowing MNEs to exploit economies of scale, since similar products may be sold in several countries at the same time.

The failure of the majority of the developing countries to develop the necessary created assets, especially those of skilled human capital and infrastructural facilities, underly the limited extent to which affiliates in developing countries have been involved in the process of rationalisation. Nonetheless, there are some benefits of reduced transaction costs from ICT for developing countries. First, information about policies, incentives and procedures are much more widely disseminated. Second, countries are able to compete more effectively with other locations for investment. Third, they are better able to coordinate activities within the country (between, say, regions that are competing for investment) and between various arms of policy makers and agencies through one-stop shopping (Wells and Wint 1993).

A second feature of new technologies has been the emergence and development of entirely new industries, which have generated entirely new sources of employment both in the manufacturing and services sectors. Indeed, the mushrooming of new industries has been attributed to the productivity paradox (Freeman and Soete 1994, OECD 1996). Despite the growth and proliferation of ICT, there has been a marked lack of improvement in the overall productivity statistics of most countries. The fact that the productivity growth in the manufacturing sector due to new technologies has been 'averaged' out by growth in the 'service' part of manufacturing has been postulated as one of the primary explanations for the productivity paradox. As noted recently, $70 \%$ of the revenues in the computer industry come from products that did not exist two years previously (Woodall 1996). The difference in the extent to which these developments have affected the converging and the diverging countries is not as acute as elsewhere for the simple reason that because these 
are new technologies, there is not likely to be as large a 'gap' between the lead and lag countries. Indeed, developing countries have attempted a 'niche' strategy in developing created assets by specialising in particular new technologies as a way of achieving competitiveness - the often cited example of India's burgeoning software sector and the focus of other nations in biotechnology is another (Acharya 1995). However, the failure of the majority of developing countries to exploit these new technologies has acted as a centripetal force, encouraging centralisation of production to within the Triad by MNEs.

Third, new technologies have led to truncated product life cycles which have led to new or modified products are more rapidly developed and manufactured. Firms are able to undertake technological developments and are able to bring them to market much more rapidly than was previously the case. Computer-aided design (CAD) as well as developments in 'flexible' manufacturing systems and computeraided manufacturing have further reduced the set-up costs and time taken to bring a new product to market. Although this has led to a reduction in fixed costs associated with new products, these technologies are not costless. First, rapid product life cycles imply a relatively high R\&D intensity if firms need to remain competitive. They also suggest that an innovating firm needs to quickly recoup these high fixed costs, before its technology become redundant especially so if a rival firm wins the 'race' to innovate the next generation product $^{8}$. It must therefore (a) sell at a relatively high cost per unit, and/or (b) develop a production process with a low minimum efficient scale and/or (c) recoup its investment by acquiring a large market for its products so as to spread its fixed costs. However, whichever strategy a firm undertakes, it generally enhances the need for it to seek and expand overseas markets. Once again, target markets tend to be those with similar income and consumption patterns, rather than the diverging developing countries, where multidomestic strategies still prevail, and for whose markets products for which the R\&D costs have already been amortised.

\section{(ii) Renaissance of market-based capitalism and economic liberalisation}

The 1980s were a decade of considerable ideological and economic upheaval. In particular, we would mention three events, which, although separate, have common roots. First, the cold war ended. Since 1989 more than 30 countries have abandoned central planning as the main mode of allocating scarce resources. Second, over 80 developing countries have liberalised their economic policies from inward looking, importsubstituting regimes towards export-oriented, outward looking policy frameworks. Between them, these two developments have led to, a liberalisation of attitudes of national governments towards inward FDI, the privatisation of state owned enterprises, and the reduction of structural market distortions. MNEs are now actively involved in, and have access to, an unprecedented number of countries. UNCTAD (1995) suggests that of 110 new norms adopted by 49 countries with respect to their national FDI regimes, 108 were in the direction of encouraging, and only two in the direction of discouraging FDI. This trend has continued and deepened during the 1990s.

8 Patent protection is a highly imperfect tool to protect an inventor from competition, eespecially so $\mathrm{n}$ industries where technological change is rapid and competition high. As such, an innovating firm's only way of maintaining its competitive advantage may be by being 'first', and remaining in the lead in subsequent rounds of innovation (Levin et al 1987). 
Third, there has been an across-the-board liberalisation of a variety of cross-border markets due to (i) regional and inter-regional free trade agreements and protocols, e.g., the completion of the European single market, NAFTA and MERCOSUR ${ }^{9}$, (ii) a range of bilateral arrangements; and (iii) multilateral, binding arrangements such as the establishment of the World Trade Organisation (WTO) and the completion of the Uruguay round of GATT. Each of these agreements has contributed towards a reduction in barriers to trade. In addition, in recent years increasing attention has been paid to agreements which liberalise the flow of FDI and other forms of MNE activity, such as the General Agreement on Trade in Services (GATS), Trade Related Investment Measures agreement (TRIMs) and Trade Related Intellectual Property Rights agreement (TRIPS). Although some of these agreements, such as TRIMS and TRIPS existed prior to the establishment of WTO, they have become much more specific, and are explicitly aimed at being upgradeable. Furthermore, FDI-related disputes can now be brought directly into the WTO disputes settlement process (Brewer, 1996)

What has this meant for FDI and MNE activity and MNE-government relations? Privatisation, in particular, has allowed MNEs to acquire, in one fell swoop, fully-operational (albeit inefficient) firms in countries with relatively low levels of domestic competition but significant market potential, and - due to overvalued exchange rates - at relatively low cost. Over the period 1989-93, FDI from privatisation accounted for $\$ 12.2$ billion or $7.6 \%$ of all inflows to developing countries. Over $75 \%$ of this was directed towards Latin America and the Caribbean, where privatisation accounted for $16.9 \%$ of all inflows to the region. In the case of central and eastern Europe, FDI inflows to privatisation schemes amounted to $\$ 7.5$ billion, or $59.7 \%$ of the total FDI inflows to the region. Average tariffs and non tariff barriers have fallen considerably, and affiliates of MNEs are increasingly given national treatment.

However, the news is not as good for emerging economies. The increased competition between countries offering favourable investment climates for both domestic and foreign investment has increased significantly. While the value of FDI directed towards developing countries may have increased, an increasing proportion of new investment is of an asset-acquiring kind and/or requires the use of specialised created assets, and therefore tends to be directed to the developed and wealthier developing countries. Liberalisation, on the other hand, has meant that a much larger (possibly twice as many as two decades previously) pool of countries offer 'generic' $\mathrm{L}$ advantages such as access to natural assets and basic infrastructure. The problem of too many countries chasing too little FDI is exacerbated by the competition between provinces and regions within countries which offer their own set of incentives schemes to funnel scarce investments to their locations (Mytelka 1996). Countries and provinces are therefore under pressure to 'give away' bigger investment incentives in order to attract the FDI that is often central to their development strategies. Furthermore, inflows from privatisation represent a single, one-off phenomenon - MNE acquisitions through privatisation schemes may initially generate a large initial infusion of capital, but subsequent inflows are by no means guaranteed. Indeed, because MNEs intend to generate some rents from these investments the net inflows can be expected to be significantly smaller in subsequent years.

9 There are also non-binding agreements and protocols such as the OECD code of liberalisation of capital movements (which are binding upon member states, but not on non-members) and guidelines for multinational enterprises. 


\section{THE COMPETITIVE POSITION OF COUNTRIES AND THE ROLE OF MNE ACTIVITY}

The decline and/or stagnation in the economic development of the diverging (and poorer) countries directly effects the competitiveness of these countries and that of their firms. Competitiveness is increasingly determined by a country's location specific advantages, and particularly the mechanisms and institutions that encourage the evolution of created assets from natural assets (see e.g., Narula 1993, 1995, Dunning 1993, Dunning and Narula 1995, Narula and Wakelin 1995).

Abramovitz (1990) suggests a similar argument that the tendency to converge depends on the countries in question having similar social capability and technological congruence. By social capability, he means the political, cultural and economic and social infrastructure associated with a country. The second condition - that of technological congruence - is a function of the capability of a country to benefit from technological spillovers from leading countries, and its ability to accumulate technology. Not all countries will be equally able to catch up in all industries; the extent to which this is possible will depend on the nature and level of its created and natural assets as well as the characteristics of its markets. Neither will every country will be able to exploit its full potential for rapid growth because of resource constraints and limited or underdeveloped markets. This situation is bound to get worse with divergence: as the economic distance between a diverging economy and the lead countries increases, the product overlap decreases, therefore inhibiting the laggard country's ability to catch-up with lead country due to the reduced opportunities for technological spillovers. Hansson and Henrekson (1995) have also suggested that, in addition to these two factors, increased trade intensity and an outward looking policy orientation significantly facilitate the convergence process.

Indeed, the failure of countries to improve the quality of their immobile resources and capabilities emphasises the role of governments in overcoming the failure of markets to do so. The development and maintenance of the created assets of a country is crucial not only as a basis for encouraging entrepreneurship and the growth of domestic enterprises, the ability of firms to harness new technologies and skills through, inter alia, the availability of skilled human capital. Nonetheless, if firms are to generate $\mathrm{O}$ advantages that allow it to compete on international markets (and which is increasingly the case due to the wholesale liberalisation of markets) it must acquire or develop these over a period of time. It is important to emphasise that $\mathrm{O}$ advantages include not just technology in a traditional sense, but (i) the organisational skills to coordinate intra-firm activities (ii) the knowledge of markets to efficiently acquire inputs from suppliers; (iii) familiarity with markets to efficiently sell their outputs and (iv) the ability to efficiently utilise information about technology/markets/organisations that is specific to another firm, a group of individuals or to a location. The last point needs further clarification. Created assets such as information are generally context specific ${ }^{10}$, in as much as they are specific to the firm which is currently utilising it, and cannot be efficiently used by

10 Due to the path dependency of information and the bounded rationality of firms, learning is a localised procedure. 
another individual or firm unless the technology is 'learnt', (i.e., made firm-specific) by the recipient firm. This also applies to information that is embodied in skills possessed by human capital in a given location. Since such learning is a gradual process, it is by no means costless, and the efficiency with which a given firm can make a given technology firm-specific determines the actual cost. This argument is similar to the thesis advanced by Stiglitz (1987) that firms must "learn to learn". According to Nelson and Pack (1995) the ability of learning to learn is an important determinant of the success of the Asian NICs.

In order to catch-up, then, a country must enhance the ability of its firms to have access to, and effectively utilise the stock of knowledge available to the firms in countries which are economically and technologically more advanced than itself. Put another way, domestic firms must have the opportunity to combine their own competitive advantages and location-specific assets of its home country with those of their counterparts in foreign countries. As governments have come to a "new" realisation regarding the fundamental need to enhance the $\mathrm{O}$ advantages of its firms, further encouraged by the much-publicised successes of the East-Asian newly industrialising economies, they have increasingly sought out MNEs. Indeed, as Sanjaya Lall (1995: pg 5) has cogently expressed it,

"Transnational corporations are amongst the most powerful means available for transferring modern technologies by developing countries and overcoming obstacles to their utilisation. By virtue of their large internal markets for capital, skills and technology and information, they face fewer market failures than local firms. In most circumstances, therefore, there is no reason to restrict entry-their presence can only benefit local productivity and competitiveness. Moreover, since TNCs are at the forefront of innovation, their presence provides an effective means of keeping up with technical progress. Their established brand names, global marketing presence and international flows of information all add to their technological advantages"

Indeed, the use of MNEs as a source of technology, information and human resource development has been a primary strategy of many NICs, although some countries (e.g., Korea) have preferred to use market and quasi-market mechanisms such as licensing, joint ventures and turnkey projects to obtain such assets, while others such as Taiwan have encouraged MNEs to engage in FDI (Lall 1995, Dunning, Hoesel and Narula 1996). The preference for reliance on purely markets firms of transfer tends to diminish as the nature of technology and information becomes more idiosyncratic and firm-specific. As such, the role of L advantages is two-fold: first, as the basis for the growth of domestic enterprises, and second as a means to attract MNEs to engage in value adding activities.

What form should the government intervention to enhance created assets take? It is by now generally agreed that MNE-specific created assets cannot be diffused costlessly or instantly to the host country's domestic economy, (see, e.g., Teece 1977, Cantwell 1991, Amsden 1992) and it is one of the tasks of government to manipulate these to improve the competitiveness of its firms. The extent of government intervention depends on several factors. The exact nature of policies is outside the scope of the present chapter, but some broad objectives of government intervention can be stated here, depending on the overall long-term economic strategy of the country. First, even where the MNE is willing to utilise its competitive advantages in conjunction with the immobile created assets of countries, there need to be domestic firms that have both the access to the complementary assets and possess the competitive advantages necessary to take advantage of spillovers. These include not just firms in the same industry, but those in related industries such 
as supplier firms. For instance, were, say, Ghana to attract investment in the aerospace industry, the absence of domestic firms with the complementary assets to efficiently utilise the externalities from the direct and indirect technology spillovers would lead to minimal benefits for the host country. Second, the competitive assets of both domestic and foreign-owned firms need to be sustained in the face of international competition using supporting institutions. These institutions include the legal infrastructure to protect existing assets through strong (and enforceable) patent laws, but the ability to develop new assets. In a dynamic economy, firms have to continually invest in innovatory and training activities in order to maintain their competitive advantages, but these require the use of country-specific created assets, such as an adequate supply of skilled labour and appropriate macro-organisational policies, R\&D subsidies, etc. Third, domestic firms must have some incentive to reinforce their technological assets and competitive advantages over time, by exposure to international competitors. Captive markets and oligoplistic positions do not act as an incentive to upgrade created assets, as was shown by the state of the Indian manufacturing industry prior to liberalisation. Fourth, MNEs must have some incentive to allow for a deliberate attrition of their competitive advantages. This may take the form of (privileged) access to domestic markets (e.g.., automobile firms in China), or subsidised or exclusive rights to certain natural assets (Aramco in Saudi Arabia). These issues have been studied in greater detail elsewhere by several other scholars (see Lall 1990, 1995, Amsden 1992, Hikino and Amsden 1994, Wade 1988, Ozawa 1995) and will not be re-examined here.

\section{DIVERGING ECONOMIES AND FDI: SOME POLICY IMPLICATIONS}

The preceding discussion would seem to suggest the following conclusions. First, that the growing interdependence of countries and their convergence of income and technological levels and consumption patterns is peculiar to the wealthier industrial countries and a minority of developing countries, e.g., NICs and China. Second, that the failure of the rest of the developing world to achieve convergence and catch-up is associated with the inadequate and -often declining - level of domestic created assets and the inefficiency of local firms. Third, that although the involvement of MNEs in the diverging economies appears to have increased over the last decade, this may be attributable to their economic decline as well as one-of increases due to privatisation, without which divergence may have even more pronounced. Fourth, an increasingly important means by which to upgrade their competitiveness has been the importation of technology, skills and organisational capabilities, and the access to foreign markets provided by foreign firms, both via FDI and by collaborative arrangements of one kind or another. Fifth, that the conditions for catch-up and convergence are also the necessary (but not sufficient) conditions to attract FDI. That is, there is a certain threshold level of created assets associated with a given location and its resident firms which determine the ability of these firms to benefit from externalities that arise from MNE-related activity, and that a threshold level of created assets and industry clusters are also necessary as L advantages to attract such activity in the same place.

Herein lies the chicken-and-egg dilemma that faces countries that wish to duplicate the success of the Asian NICs. Countries clearly need to improve their L advantages, primarily through the growth of their created assets, if their firms are to become more competitive. One source of capital and created assets to achieve this is through MNE activity, which prefer to invest where such $\mathrm{L}$ advantages already exist. It is also 
clear from recent evidence ${ }^{11}$ that simple prescriptions which address macroeconomic restructuring such as those associated with the World Bank programmes are insufficient by themselves: Amsden and van der Hoeven (1996) review evidence that indicates that most non-Asian developing countries that engaged in restructuring in the 1980s have experienced a collapse in investment as competitiveness seems to have been built on lower wage costs rather than higher productivity.

It is also clear that there are no guarantees that policies that have worked for one country will by necessarily work for another, given the path-dependence and idiosyncratic nature of each country and its firms, and the diverse range of policies that each country has followed. Nor, indeed, have all countries benefit from the vagaries of international politics equally. For example, it is no secret that countries such as Korea and Taiwan benefited enormously from cold war politics, and were able to capitalise on it, as had Japan and much of Europe a decade previously.

It would seem, nonetheless, that countries are faced with three tools in attracting FDI activity, the first two of which at the same time improve the competitiveness of their own firms. Each of these issues is deserves considerable attention and study; we can only offer a few thoughts here ${ }^{12}$. The first is that of providing and upgrading its created assets both of a general variety, and a more specific industry-specific level. These include the improvement of infrastructure, such as roads, electricity and telephones. Created assets also depend on the development of institutions to support the acquisition and creation of knowledge and wealth creating assets. This include the training of skilled human resources through educational and training schemes, intellectual property right protection, etc. These can lead to significant improvements in the transaction costs and productivity levels of domestic and foreign firms.

Second, MNE activity may be attracted through the use of appropriate macro-organisational policy, such as encouraging inward FDI into those sectors in which the country already possesses a comparative advantage in natural and created assets and industrial clusters. Such a distinction is not entirely a matter of guesswork. Ozawa (1995b) has postulated that countries at earlier stages of their investment development paths tend to follow a relatively predictable process of industrial development from Hecksher-Ohlin labour intensive industries to undifferentiated Smithian and on towards differentiated Smithian (assembly type) sectors. It is only as countries proceed towards Stage 4 and towards the technology frontier that 'picking winners' becomes a risky strategy. By matching the structural upgrading of sectors and $\mathrm{L}$ advantages with the activities of MNEs and the evolution of the $\mathrm{O}$ advantages of domestic firms (as best exampled by the case of Japan and Korea ${ }^{13}$ ). Another area of macro-organisational policy worth more attention is that of coordinating trade and FDI policies. (Graham 1996). This issue has recently been explored by UNCTAD (1996)

The third tool at the disposal of governments is that of financial and fiscal incentives. However, the increasing interest in FDI as a positive economic force due to economic liberalisation discussed earlier has also led to increased competition for what is relatively the same share of FDI. This has led to a sort of

${ }^{11}$ See for instance two special issues, Journal of International Development, Vol 7, No 5, 1995 (edited by Sanjaya Lall) and World Development, Vol 22, No 4, 1994 (edited by Alice Amsden)

${ }^{12}$ And indeed has received greater attention in the work of, among others, Wade, (1988, 1990), Amsden (1990, 1992) and Lall (1990)

${ }^{13}$ See for instance the work of Ozawa (e.g., 1995a, 1995b) and Amsden $(1989,1992)$ 
'incentive war' with a record number of regions and countries competing to attract foreign investorsUNCTAD (1995) indicates that financial and fiscal incentives have increased in 93 countries between the mid-1980s and the early 1990s. However, recent research by Mudambi (1995) suggest that while incentives are not in themselves effective, the longer these incentive persist, the more likely that they will have a positive effect. At the same time, there is a danger that due to the increased competition, countries may give away more than the potential benefits that accrue from the MNE activity (Mytelka 1996, McIntyre, Narula and Trevino 1996). This is all the more so, since developing countries must compete with backward regions from industrialised countries and former centrally planned economies whose infrastructure tends to be far superior, and pockets far deeper than most developing countries. For instance, the Mercedes Benz plant in Alabama, USA attracted US\$250 million in incentives for a MNE investment of $\$ 300$ million, working out to be about $\$ 166,000$ per worker. An even higher incentive figure of $\$ 254,000$ per employee is estimated for the Volkswagen plant in Portugal (UNCTAD 1995).

Needless to say, the aim of such large per capita subsidies is long term. The objectives of policy makers in giving such incentives are twofold. First, there is the hope that the positive externalities to the local industry through indirect and direct means will resuscitate the local economy. Second, the presence of such a significant investor will act as the 'seed' investment in what governments hope will result in a healthy cluster of firms. That is, additional firms in a particular industry might be persuaded to invest in the same location either because they wish close geographic proximity to the 'seed' firm in order to act as suppliers and/or exploit externalities therefrom, or because its presence acts as a signal of the level of created assets in the region, or simply as an oligopolistic reaction in a follow-the-leader strategy. Such an clustering may result in additional economies of agglomeration, if a critical mass of firms in a given industry establish themselves. Should such a critical mass of firms develop, it reresents a significant L advantages in its own right. Indeed, a study by Head, Ries and Swanson (1994) would indicate that agglomeration is determined less by differences in resources, labour and infrastructure, but by the presence of other firms ${ }^{14}$.

This sort of footloose behaviour would seem to be typical in this age of alliance capitalism and rationalised production by MNEs. However, the increasing mobility of MNEs is a double edged sword. While it is the goal of such incentive schemes (including export processing zones) to create such a clustering of activity, it is not always a success, as affiliates can also as easily be relocated. McIntyre, Narula and Trevino (1996) list several case of EPZs which have only succeeded in attracting a minimal amount of investment. The problem, it world seem, is not just how to attract initial investments, but how to ensure sequential investments, and more importantly, how to make them 'sticky'. Furthermore, how much investment leads to a critical mass of firms such that economies of agglomeration are achieved? These are important and crucial questions that deserve further study.

These measures are by no means foolproof - and particularly in the case of the least developed countries - take considerable time to bear fruit. It must be said that the forecast for the diverging economies is not good - they are endowed with neither the time, nor the capital, to experiment with policy options -

\footnotetext{
${ }^{14}$ It should be noted that most successful centres of agglomeration have resulted from an increasing pattern of specialisation over a long period, i.e., they have 'historical' origins.
} 
divergence leads to a continuing shrinking of market size in real terms and a growing technological gap, which also results in the gradual loss of interest in these markets by MNEs as potential economies of scale and scope are eroded. Furthermore, diverging economies themselves are not a homogenous group, as their numbers include a host of former centrally planned economies who are relatively well endowed with certain kinds of created assets, and which are in a better position both strategically and economically to catch-up than others.

It is germane to add a note of caution to this discussion. The increased role of MNEs in the least developed countries has meant that MNEs are increasingly significant players in the economic development of these countries, and can directly influence the direction and nature of structural adjustment, given their economic clout. There is little or no basis to assume that MNEs will or have used their privileged position to affect decisions that will necessarily increase economic development. Whether, or to what extent, MNEs have resulted in structural maladjustment is not known, but there certainly exists considerable potential for such effects to occur. 
$\underline{\text { References }}$

Abramovitz, M. (1990) The catch-up factor in postwar economic growth, Economic Inquiry, Vol 28, January, pp 1-18

Acharya, R. (1996) The Biotechnology Revolution, Edward Elgar, Aldershot

Alam, M. and Naseer, A. (1992) Convergence and polarisation: testing for an inverted-u relation between growth rates and GDP per capita, Applied Economics, Vol 24, pp 363-

Amsden, A. (1989) Asia's Next Giant, New York, Oxford University Press

Amsden, A. (1992) A theory of government intervention in late industrialisation, in L. Putterman and D. Rueschemeyer (eds) State and Market: Rivalry or Synergy? Lynee Rienner, Boulder

Amsden, A. and van der Hoeven, R. (1996) Manufacturing output, employment and real wages in the 1980s: labour's loss until the century's end, Journal of Development Studies, Vol 32, No 4, pp 506-530

Brewer, T. (1996) Multilateral investment agreements in the new era of foreign direct investment: implications for India and other emerging market economies, Foreign Trade Review, forthcoming

Dowrick, S. (1992) Technological catch up and diverging incomes: patterns of economic growth 1960-88 The Economic Journal, Vol 102,May, pp 600-610

Dowrick, S. and Gemmell, N. (1991) Industrialisation, catching up and economic growth: a comparative study across the world's capitalist economies, The Economic Journal, Vol 101, March, pp 263-75

Datta-Chaudhuri, Mrinal (1990) Market failure and government failure, Journal of Economic Perspectives, Vol 4, Summer, pp 25-39

Dunning, J.H. (1993) Multinational Enterprises and the Global Economy, Wokingham: Addison Wesley

Dunning, J.H (1994) Globalisation, Economic Restructuring and Development, The Raul Prebisch Lectures, Geneva: UNCTAD

Dunning, J.H. (1995) Reappraising the eclectic paradigm in an age of alliance capitalism, Journal of International Business Studies Vol 26, pp 461-91

Dunning J.H. (1996) The Changing Geography of Foreign Direct Investment, paper presented at UNU/INTECH international workshop on foreign direct investment, technology transfer and export orientation in developing countries, Maastricht, November

Dunning, J.H. and Narula, R. (1994) Transpacific Direct Investment and the Investment Development Path: The Record Assessed, Essays in International Business, March

Dunning, J.H. and Narula, R. (1995) The investment development path revisited:some emerging issues, in J. Dunning and R. Narula (eds), Foreign Direct Investment and Governments: Catalysts for Economic Restructuring, London: Routledge.

Dunning, J.H. van Hoesel, R. and Narula, R. (1996) Explaining The 'New' Wave Of Outward FDI From Developing Countries, MERIT Working Paper Series No 96-013 (forthcoming, 1997, International Business Review.)

Duysters, G. and R.Narula (1996) International Strategic Technology Partnering by EU Firms: Globalisation or Integration?, MERIT Research Memoranda 96-25 
Freeman C. (1987) The challenge of new technologies in interdependence and cooperation, in Tommorrow's world, OECD, Paris, pp 123-56

Freeman, C. and Hagedoorn, J. (1995) Convergence and Divergence in the Internationalisation of Technology, in J. Hagedoorn (ed), Technical Change and the World Economy, Edward Elgar, Aldershot

Freeman, C. and C. Perez (1988) Structural crises of adjustment, business cycles and investment behaviour, in Dosi et al (eds) Technical Change and Economic Theory, London: Pinter

Freeman C.and Soete L. (1994) Work for All or Mass Unemployment, London: Pinter

Graham, E. (1996) Global Corporations and National Governments, Institute for International Economics, Washington DC

Gray, H.P. (1996) Globalization and Economic Development, mimeo, Rutgers University, Newark

Hansson, P. and Henrekson, M. (1995) What makes a country socially capable of catching up? Weltwirtschaftlishes Archiv, pp 760-783

Hagedoorn, J. and Narula, R. (1996) Choosing modes of governance for strategic technology partnering: international and sectoral differences, ${ }_{2}$ Journal of International Business Studies Vol 27, pp 265-284

Head, K., Ries, J and D. Swenson (1994) Agglomeration Benefits and Location Choice: Evidence from Japanese manufacturing Investment in the United States, NBER Working Paper no 4767

Lall, S. (1990) Building Industrial Competitiveness in Developing Countries, Paris, OECD

Lall, S. (1995) Industrial strategy and policies on foreign direct investment in East Asia, Transnational Corporations, Vol 4, December, pp 1-26

Levin, R., Klevorick, A., Nelson, R., and S.Winter (1987) Appropriating the returns from industrial research and development, Brookings Papers on Economics Activity, No 3, pp 783-820

Lall, S. (1996) The investment development path: some conclusions, in J. Dunning and R. Narula (eds), Foreign Direct Investment and Governments: Catalysts for Economic Restructuring, London: Routledge, pp $423-441$

Lundvall, B.(1992) National Systems of Innovation: Towards a Theory of Innovation and Interactive Learning, London, Pinter Publishers

McIntyre, J., Narula, R. and Trevino, L. (1996) The role of export processing zones for host countries and multinationals: a mutually beneficial relationship? International Trade Journal, Vol 10, Winter (forthcoming).

Mytelka, L (1996) Locational Tournaments, Strategic Partnerships and The State, mimeo, Carleton University, Ottawa

Narula, R. (1993) Technology, international business and Porter's 'diamond': synthesising a dynamic competitive development model, Management International Review, vol 33, pp 85-107

Narula, R. and Wakelin, K. (1995) Technological Competitiveness, FDI and Trade, MERIT Working Paper Series No 95-20

Nelson, R. and Winter, S. (1982) An Evolutionary Theory of Economic Change, Belknap Press, Cambridge

Nelson, R. and Pack, H.(1995) The Asian Growth Miracle and Modern Growth Theory, New York, Columbia University, mimeo

Mudambi, R. (1995) The MNE investment location decision: some empirical evidence, Managerial and Decision Economics, Vol 16, 249-257 
Narula, R. (1995) Multinational Investment and Economic Structure, Routledge, London

OECD (1996) Technology, Productivity and Job Creation, OECD, Paris

Ozawa, T. (1995a) Japan: the macro-IDP, meso-IDPs and the technology development path (TDP), in J. Dunning and R. Narula (eds), Foreign Direct Investment and Governments: Catalysts for Economic Restructuring, London: Routledge, pp 423-441

Ozawa, T. (1995b) Structural upgrading and concatenated integration, in D Simon (ed) Corporate Strategies in the Pacific Rim: Global versus Regional Trends, Routledge, London, pp 215-246

Stiglitz, J. (1987) Learning to learn, localised learning, and technical progress, in P. Dasgupta and P. Stoneman (eds) Economic Policy and Technological Progress, Cambridge: Cambridge University Press

Teece, D.J. (1977) Technology transfer by multinational firms: The resource cost of transferring technological knowhow, Economic Journal, Vol 22, pp 242-61

UN (1993) Small and Medium-Sized Transnational Corporations, United Nations, New York

Woodall, P. (1996) A Survey of the World Economy, the Economist,September 28th-October 4th

UNCTAD (1995) World Investment Report 1995 Geneva,United Nations

UNCTAD (1996) World Investment Report 1996 Geneva,United Nations

Wade, R. (1988) The role of government in overcoming market failure in Taiwan, Republic of Korea and Japan, in Hughes, H. (ed), Achieving Industrialiation in East Asia, Cambridge: Cambridge University Press

Wade, R. (1990) Governing the Market: Economic Theory and the Role of Government in East Asian Industrialization, Princeton NJ, Princeton University Press

Wells, L.T. and A. Wint (1993) Don't stop with the one-stop shop: foreign investment in a liberalising third world, International Executive, Vol 35, pp 367-384

World Bank (vd) The World Development Report, Oxford, Oxford University Press 